\title{
Law Review
}

\section{9/1 \\ EELC's review of the year 2018}

CONTRIBUTORS Ruben Houweling, Catherine Barnard, Filip Dorssemont, Jean-Philippe Lhernould, Francesca Maffei, Niklas Bruun, Anthony Kerr, Jan-Pieter Vos, Luca Ratti, Daiva Petrylaite, Andrej Poruban and Stein Evju

\section{Introduction}

Never a dull moment, is quite an understatement when looking back on 2018. While parts of Europe flourish due to economic growth, leaving the recession far behind, other parts of Europe are facing economic challenges and, with it, labour market issues. Italy, for example, is struggling with the EU when it comes to controlling its national budget and introducing labour market reforms, especially to combat youth unemployment. There seems to be a growing tension between the 'haves' and the 'have nots' not only between countries but also within them. This spells polarization.

This polarization is strongly embodied by the (originally) French 'yellow vests movement'. Among other things, like environment and migration, one of the key demands of this movement is a 'fair income'. Wasn't fair income one of the ILO-principles? Even though the yellow vests movement is connected to France, all across Europe similar movements are visible. But it seems fair to say that no country was (and still is) more polarized than Great Britain due to the Brexit debate. While time is running out and the no-deal-scenario is still firmly on the table, leaving the EU has a great impact both within Britain and on the mainland. Companies are relocating their headquarters to stay, or deliberately not to stay, within the scope of the fundamental freedoms of Europe.

With these stormy winds blowing across Europe, one might forget that the ECJ once again ruled on some landmark cases. In Matzak, for example, the Court decided that the time spent at home but still being available to the employer qualifies as 'working time' (see Kerr's contribution). In Egenberger the Court had to resolve a dispute between two private parties in finding the balance between religious freedom and nondiscrimination. More specifically, it also considered whether the Directive allows a church or religious organisation authoritatively to determine (i.e. without substantive judicial scrutiny) whether religious affiliation constitutes a genuine occupational requirement. The Court decided that where a church or religious body asserts, because of its ethos, that religious belief constitutes a genuine occupational requirement for employment, it must at least be possible for such an assertion to be the subject, if need be, of effective judicial review (EELC's next issue will contain a detailed discussion about this judgment).

But maybe the most debated judgments of the ECJ in 2018 are the November rulings on 'paid leave'. Although the consequences of registration and the role of the employer to promote paid leave in the light of time limitations, as stressed in Max Planck and Conley King, will have a great impact in daily practice, it is the proclaimed 'direct horizontal application' of (parts of) the EU Charter of Fundamental Rights (Bauer-case) that attracted the greatest attention to the Court's judgments in 2018 (see Vos\&Ratti hereafter)! National judges need to disregard provisions that are contrary to, in this case, Article 31(2) CFREU. Of course the question is to what extent the Bauer judgment applies to other 'fundamental social rights' in the Charter and what the consequences are or should be regarding the nonhorizontality of directives dealing with social rights that are covered in the Charter.

The rulings highlighted here, together with the political debates, are but a few of the interesting developments of 2018. This EELC review elaborates and analyses the different rulings of the ECJ and national courts. After reading all the contributions, there is only one way to answer the following question: Europe in 2018, a dull moment? Never! And what does that have to say about 2019...? We'll keep you posted in EELC!

Prof. C. (Catherine) Barnard and prof. A.R. (Ruben) Houweling 


\section{Age \& disability discrimination}

\section{Prof. Filip Dorssemont ${ }^{1}$}

Age

The Framework Directive 2000/78/EC establishing a general framework for equal treatment in employment and occupation prohibits discrimination based upon age in the field of employment and occupation.

The ECJ case Fries (C-190/16) needs to be highlighted, since it deals with the fundamental rights underlying the Framework Directive, id est the principle of nondiscrimination based upon age (Article 21 CFREU) and the right to engage in work (Article 15 CFREU). These provisions were mobilized within the framework of a preliminary procedure against an instrument of $\mathrm{EU}$ secondary law (Regulation No. 1178/2011) severely restricting the legal capacity of licensed pilots to operate commercial air transport when aged over 60 , especially when aged 65. As a result of this Regulation, the contract of Fries was terminated by Lufthansa. The attempt of Fries to declare this provision of EU law imposing an age limit contrary to these Charter provisions in what is a horizontal conflict between Lufthansa and one of its pilots was considered to be ill-founded. The ECJ, referring to Article $52 \mathrm{CFREU}$, considered that there was a legitimate aim to restrict the principle of nondiscrimination (security) and that the proportionality principle was not violated. Hence, the leeway to restrict the principle of discrimination under Article 21 is significantly larger than the leeway to justify discrimination under EU Directive 2000/78, especially if one considers the potential spill over of this judgment in relation to other grounds.

In Stollwitzer (C-482/16) a piece of Austrian legislation regarding the pay scales applicable to the Austrian railways $(\mathrm{OBB})$ was alleged to be contrary to the principle of age discrimination. The legislative intervention sought to correct the previous position of the article that working experience commenced prior to the age of 18 years old was not taken into account at all for the purpose of calculating the pay scales. After the amendment, Stollwitzer's juvenile working experience continued to be disregarded based upon the consideration that it related to another branch of industry than the railways. The ECJ considered that the Austrian law did not constitute either direct or indirect discrimination.

\section{Disability}

The Framework Directive 2000/78 establishing a general framework for equal treatment in employment and occupation prohibits discrimination based upon disability in the field of employment and occupation.

In Bedi (C-312/17), the ECJ had to dwell both on the notion of employment and occupation as defined in the Directive. Furthermore, it had to assess whether a regime which allowed for a differentiation of the pay-

1. Filip Dorssemont is a Professor of Labour Law at the Universite catholique de Louvain. ment of bridging assistance depending on the disability of the worker had to be considered as discriminatory and could be justified at all. Under the applicable German rules, severely disabled persons active in the military service in Germany had access to (automatic) early retirement at an earlier age. As a result of this situation, the financial situation of these persons was less advantageous than those who could not yet retire, but were receiving these bridging assistance payments, e.g. in combination with wages resulting from another job outside the armed forces.

The Court ruled that the issue of bridging assistance payments based upon a collective agreement did not fall outside the sphere of employment and occupation, despite the exclusion of social security. It also ruled that the situation did constitute discrimination based upon disability.

On 20 February 2018, the (appellate) Labour Court of Brussels ruled that the dismissal of an employee diagnosed with lymph node cancer constituted discrimination based upon disability (EELC 2018/23). The disease had generated a situation which entailed limitations resulting in particular from long term physical, mental or psychological impairments which, in interaction with various barriers, hindered the full and effective participation of the person concerned in professional life on equal basis with other workers. In casu, the employer had never considered adapting the employee's job, thus violating the duty of reasonable accommodation. This duty is not absolute. Thus, the Irish Court of Appeal has ruled in a judgment of 31 January 2018 (EELC 2018/12) that the refusal to provide another job to a person paralyzed after an accident from the waist down and requiring a wheelchair was not discriminatory, in so far as that person was not able anymore to perform any of their previous tasks essential to their position as 'special needs assistant'.

\section{Free movement}

\section{Prof. Jean-Philippe Lhernould ${ }^{2}$}

Posting remains the most sensitive subject in conjunction with risks of fraud and social dumping. A series of cases help clarify the applicable rules. The Altun case (C-359/16) admits, for the first time, that a national court may, in the context of proceedings brought against persons suspected of having used posted workers ostensibly covered by A1 certificates, disregard those certificates if, on the basis of evidence and with due regard to the safeguards inherent in the right to a fair trial which must be granted to those persons, it finds the existence of such fraud. This case should not be misinterpreted: conditions set by the Court of Justice are so strict that it is only in exceptional cases that $\mathrm{A} 1$ certificates can be ignored by national Courts. In Alpenrind (C-527/16), the ECJ indeed reinforces the binding effect attached to 
an A1 certificate. It may even be binding, if appropriate with retroactive effect, even though that certificate was issued only after the receiving Member State determined that the worker concerned was subject to compulsory insurance under its legislation. Unsurprisingly, in line with this case law, the ECJ subsequently considered that Belgium had failed to fulfil its obligations under Regulation No. 883/2004 by entitling the competent national authorities to require, unilaterally and without following the dialogue and conciliation procedure set out in the Regulation, that the national legislation on social security matters is to apply to posted workers who are already subject to a social security scheme in the Member State in which their employer normally carries out its activities, on the grounds that the issuing by the social security body of that Member State of a document showing that such workers are subject to the social security scheme of that Member State ('A1 certificate') is an abuse of rights (Commission - $v-$ Belgium, C-356/15).

The risk of fraudulent posting was in the background of three more cases. In the first one (Alpenrind), the ECJ held that if a worker who is posted by his employer to carry out work in another Member State is replaced by another worker posted by another employer, the latter employee must be regarded as being 'sent to replace another person', within the meaning of Article 12(1) of Regulation $883 / 2004$, so that he cannot benefit from the special rules laid down in that provision in order to remain subject to the legislation of the Member State in which his employer normally carries out its activities. In other words, a posted worker cannot be immediately replaced by another posted worker from a different company without breaching the 'non-replacement' rule set out in Article 12(1) of Regulation 883/2004. This ruling is clearly influenced by the principle of equality of treatment (of remuneration) between workers performing their activity at the same place, against the principle of free movement of services which the Advocate-General promoted in its opinion. This being said, as the second case indicates, the ECJ remains vigilant vis-à-vis national rules designed to combat illegal posting rules. In Cepelnik (C-33/17), the Court decided that Article 56 TFEU precludes legislation of a Member State under which the competent authorities can order a commissioning party established in that Member State to suspend payments to their contractor established in another Member State, or even to pay a security in an amount equivalent to the price still owed for the works in order to guarantee payment of the fine which might be imposed on that contractor in the event of a proven infringement of the labour law of the first Member State. This case is a reminder for all Member States which keep increasing administrative, civil and criminal sanctions to tackle illegal posting, losing sight of the fact that national measures which are liable to restrict or to make less attractive the exercise of the fundamental freedoms guaranteed by the TFEU may be permitted only where they serve overriding reasons in the public interest, are appropriate for attaining their objective, and do not go beyond what is necessary to attain that objective. A last posting case gave the ECJ the opportunity to rule that an employee recruited with a view to being posted to another Member State must be regarded as having been 'just before the start of his employment ... already subject to the legislation of the Member State in which his employer is established' even if that employee was not an insured person under the legislation of that Member State immediately before the start of his employment, if, at that time, that employee had his residence in that Member State (Wallopia, C-451/17). This case, which consolidates the content of the practical guide issued by the Commission, facilitates posting operations while at the same time avoiding the absence of social security legislation applicable to nonactive mobile persons. One important question remains though: How long should a person be subject to a certain legislation before posting is allowed? Should the one-month period set out in an administrative decision be compatible with rules on free movement of services? Concerning the determination of the social security law applicable to migrant workers, the ECJ clarified specific situations where a person carries out an activity in two Member States. It held that a person residing and employed in the territory of one Member State who, for a period of three months, takes unpaid leave and is employed in the territory of another Member State, is to be regarded as normally employed in the territory of two Member States within the meaning of that provision, provided that, during that period of leave, he is considered as normally employed under the social security legislation of the first Member State and that the activity carried out in the territory of the second Member State is habitual and significant in nature $(X$, C-569/15). On the same day, the Court held that a person who is employed by an employer established in the territory of one Member State and who resides in another Member State where he carried out, over the course of the past year, a part of his employment activity amounting to $6.5 \%$ of his hours worked without such an arrangement having been agreed with his employer in advance, is not to be considered to be normally employed in the territory of two Member States $(X$, C-570/15). Even though these two cases are connected with the former Regulation 1408/71, they remain relevant under Regulation $883 / 2004$ which provides that a person who normally pursues an activity as an employed person in two or more Member States is subject to the legislation of the Member State of residence if he/she pursues a 'substantial part' of his/her activity in that Member State. It is necessary to derogate from the general rule of connection to the Member State of employment only in specific situations which demonstrate that another connection is more appropriate.

Contrary to other social security benefits, the exportation of unemployment benefits in other countries is limited in time. Entitlement is retained for only three months, but the competent institutions may extend the period up to a maximum of six months. How should the extension rule be understood? While recalling that that 
provision does not require the competent institutions to extend up to a maximum of six months, the ECJ draws a clear line between two types of countries, those which have not activated the extension option and those which have done so. In this last case, it is required that countries must adopt national measures regulating the competent institution's discretion, in particular by specifying the conditions on which extension of the unemployment benefit export period beyond three months is or is not to be granted (Schiphorst, C-551/16). The current discussion of the revision of Regulation 883/2004 could lead to the extension of the exportation to a sixmonth minimum period, but the competent services or institutions may extend that period up to 'the end of the period of entitlement to benefits'. The solution adopted in Schiphorst would be transposable to this new extension.

A quite interesting question derives from the right to retain the status of worker under Directive 2004/38: Should a Union citizen who is no longer a selfemployed person retain this status for the reason that, according to Article 7(3)(b) of Directive 2004/38/EC, he has 'duly recorded involuntary unemployment'. The answer given is positive (Gusa, C-442/16). This state indeed covers self-employed workers who ceased their activity because of absence of work owing to reasons beyond their control. This far-reaching interpretation of the Directive, which is motivated by the will to strengthen the fundamental right of all Union citizens to move and reside freely without making differences between employed and self-employed workers, is daring. In our view, a similar solution could have been reached more simply by applying Article 56 TFEU (compare with Commission $-v-$ Luxembourg, C-111/91).

A last case about access to reliance on care-related benefit by a cross-border student deserves attention since it comes back to the complex matter of the coordination between Union citizens' treaty principles and social security coordination rules. The Court held that Articles 20 and 21 TFEU preclude the home municipality of a resident of a Member State who is severely disabled from refusing to grant that person a benefit, such as personal assistance, on the ground that he is staying in another Member State in order to pursue his higher education studies there $(A, \mathrm{C}-679 / 16)$. This case implicitly means that a mobile disabled person gets more rights, thanks to his Union citizen status, when the reliance on care-related benefit falls outside of the scope of Regulation 883/2004 (compare with Von Chamier, C-208/07).

\section{Fixed-term work and part-time work}

Francesca Maffei ${ }^{3}$

The number of the ECJ's rulings concerning the consistency of national legislation on 'flexible' employment contracts with European law has increased proportionally to the increasing use of these contracts by employers. Besides, the exigency to balance the employer's demand for flexibility with the employees' need for security has been always a goal of European legislation, as shown in the Council Directives concerning fixed-term and parttime work, to which this review is dedicated.

Fixed-Term Work

As far as what are referred to as fixed-term contracts, Council Directive 1999/70/EC of 28 June 1999 concerning the framework agreement on fixed-term work reached by ETUC, UNICE and CEEP, confirms that open-ended employment contracts must be in the general form of employment relationships. According to this general rule, the Directive and its annex envisages general principles and minimum requirements to be included in the rules governing fixed-term employment relationships.

In particular, scholars recognise that the Directive has a two-fold objective:

- to ensure compliance with the principle of nondiscrimination against workers employed under fixed-term contracts; and

- to prevent abuse arising from the use of successive fixed-term working relationships.

In spite of the clarity concerning its purposes, the Council Directive on fixed-term work has led to an unusually high amount of litigation on its core issues: anti-discrimination, age discrimination, prevention of abuse of fixed-term contracts and conversion of fixedterm contracts into open-ended contracts. The reason is probably found in the wide freedom the Member States have to implement the rules concerning fixed-term contracts, leaving the ECJ to verify, case-by-case, if such legislation is consistent with European law. This situation provides enormous scope for the ECJ to act as an agent in setting trends in the labour market.

An analysis of recent ECJ judgments concerning the consistency of national legislation with different key clauses of the Council Directive on fixed-term contracts (ruled in 2017-2018 and where fixed-term work is the main ground for the litigation and not a merely marginal issue) produces numerous interesting findings. It seems, indeed, that equal treatment is the most weighty issue governing the formulation of ECJ judgments on fixedterm work, followed by some statements concerning the degree of (ir)rationality in stipulating successive fixedterm contracts.

3. Francesca Maffei is a Phd in comparative law and integration process, Università degli studi della Campania Luigi Vanvitelli. 
The following lines will be dedicated to a review of these recent EJC decisions. In detail, the first section includes all the rulings regarding the possible breach of clause 4 of the Framework Agreement annexed to the Council Directive (introducing the principle of equal treatment), while in the second section the report contains all the claims in which the ECJ, in accordance with clause 5 of the Framework Agreement annexed to the Council Directive, verified the legitimacy of different national measures to prevent the successive use of fixedterm contracts.

\section{- $\quad$ Principle of Equal Treatment (clause 4)}

The principle of equal treatment (with regard to comparable workers on contracts for indefinite periods of time), as stated in clause 4 of the Framework Agreement annexed to Council Directive 1999/70, implies (for fixed-term workers) equal payment, equal access to training, and the prospect of obtaining an open-ended contract if the employment relationship continues beyond the previously agreed fixed period of time.

The list of all the rights included in the concept of the 'employment conditions' (provided for in clause 4) of permanent workers which have to be assured also to fixed-term workers is always increasing thanks to the ECJ's decisions.

Differential treatment may, however, be justified on 'objective' grounds. The following report shows that recently the ECJ emphasised these objective grounds to justify different treatment provided for in national legislation between fixed-term and permanent workers. The result is a trend of 'minimisation' of the equal treatment principle, especially for what concerns the public sector, in which the superior interest of impartiality is often considered as a strong legal basis for different treatment. For example, in the case Motter (C-466/17), the ECJ upheld the legitimacy of national legislation concerning the public sector (one provided for in a special Italian District called Provincia Autonoma di Trento, which is characterised by a wide legislative autonomy from the central Italian Government) which provided a totally different mechanism to calculate the length of service of a supply teacher hired by fixed-term contract and a permanent teacher, in order to decide the salary grade. This law was considered not in breach of clause 4(1) of the Framework Agreement because the difference in treatment was justified by the existence of an objective reason, which was not to discriminate against civil servants. Indeed, in Italy, in the public sector, permanent civil servants are recruited by competition (while supply teachers are hired by fixed-term contracts, so without competition), teach just one subject (while fixed-term workers teach a lot of subjects, so probably their professional skills could be considered as inferior to those of a civil servant) and work on a working time calculated in a different way. According to the ECJ, all these objective differences justify the different 'treatment' in calculating the length of service. Similarly, in Grupo Norte (C-574/16), different treatment between fixed-term and permanent workers was not considered as discriminatory as there were objective grounds. Under Spanish legislation, the termination of an employment contract on any of the objective grounds set out in the law confers entitlement on the worker to payment of a certain compensation equivalent to twenty days' remuneration per year of service. On the contrary, in case of termination of certain types of fixed-term contracts, on expiry of the term, the law provides for a smaller compensation.

According to the ECJ, this difference in compensation is not discriminatory, as the two different types of compensation for termination meet different objectives (the compensation for certain fixed-term workers aims to prevent excessive use of temporary employment while compensation in case of termination for objective reasons is meant to compensate for the fact that a worker's legitimate expectation that the employment relationship would continue has been frustrated). Additionally, in Mateos (C-677/16), the Court upheld the legitimacy of Spanish legislation which, in contrast to what is established for permanent workers, doesn't grant any compensation to fixed-term workers at the end of the employment contract (according to the Court, the difference is not discriminatory as the end of a fixed-term contract is foreseeable from the start, whereas the main objective of compensation for objective reasons, which generally applies to permanent workers, is to recompense them for the fact that termination of the contract is not knowable in advance).

In some situations, different treatment is allowed because there is a comparable 'right' for fixed-term workers. For example, in Viejobuena Ibáñez, C-245/17, the Court upheld the legitimacy of national legislation which provided for termination of fixed-term contracts for teachers recruited for one academic year as interim civil servants at the end of the teaching period, even if this deprived those teachers of the days of paid annual leave for that academic year (while permanent teachers always have days of paid annual leave), provided that such teachers received a specific allowance on that account.

This restrictive trend in applying the principle of equality is tempered by some other important rulings in which, on the contrary, the difference in treatment provided for in national legislation has been considered in breach of clause 4 of the Framework Agreement.

For example, in Vega Gonzàlez, C-158/16, the ECJ firstly held that the meaning of the concept of 'employment conditions' referred to in clause 4 includes the right for a worker, who has been elected to a parliamentary role, to benefit from special service leave provided for under national legislation (namely, under which the employment relationship is suspended until the end of that parliamentary term of office). Secondly, the ECJ stated that is not valid for national legislation to preclude a fixed-term worker from the special leave provided for permanent workers in a case where they may hold political office. 
- Measures to prevent abuse from the use of successive fixed-term employment contracts (clause 5)

As already stated, the second purpose of the Directive is to prevent the use of successive fixed-term contracts or relationships (clause 1). While the principle is generally fixed, the Framework Agreement (clause 5) assures to the Member States freedom to choose what kind of measure they consider best to prevent abuse from the use of successive fixed-term employment contracts. According to clause 5 of the Agreement, Member States can also adopt more than one measure and differentiate one from another depending on the sector and category of workers. What is important is that measures are proportionate, dissuasive and effective. The Court is normally asked to rule on the assessment of these measures (in terms of proportionality, dissuasiveness and effectiveness)

For example, in Santoro (C-494/16), the claim concerned Italian legislation in which the measures to prevent abuse in fixed-term contracts for the employees of public authorities and those working in the private sector are totally different. In effect, whereas a chain of fixed employment contracts in the private sector can be converted into an indefinite contract, this is not possible in the public sector. Also, in the private sector, employees can claim higher compensation (up to 14 times the last month's salary).

The differences also concern other aspects: for example, the managers of the public sector are liable for breaches of the rules on fixed contracts and, compared to the private sector, the chances of public sector workers obtaining compensation is smaller. Nevertheless, in the ruling mentioned above, the ECJ decided that such legislation was not in breach of clause 5 of the Framework Agreement as it was accompanied by an effective and dissuasive penalty mechanism for public workers (i.e. compensation of between 2.5 and 12 times the last monthly salary of those workers together with the possibility for them to obtain full compensation for the harm suffered by demonstrating, by way of presumption, the loss of opportunities to find employment or that, if a recruitment competition had been duly organised, they would have been successful).

On the contrary, in Sciotto, C-331/17, even though the case concerned the same Italian legislation, the ECJ decided in a totally different manner. In this case the claim concerned a ballet dancer at the Fondazione Teatro dell'Opera di Roma who worked under several fixedterm employment contracts so that she claimed that she had been a permanent staff member and sought a declaration that her employment contract had converted into one for an indefinite period. The National Court of Appeal dismissed her claim as the regulations containing limitations to fixed-term contracts did not apply to operatic and orchestral foundations but wondered whether this complied with EU law and asked a preliminary question to the ECJ. The decision of the ECJ was to consider this legislation in breach of EU law, not because the measures in preventing abuse in this sector are different to the ones in the private sector but because there is no other effective measure in the domestic legal system penalising abuses identified in the sector of operatic and orchestral foundations.

\section{Part-time work}

As far as part-time contracts are concerned, the analysis of two recent ECJ's rulings show that the European Court is very strict in ensuring compliance of national legislation on this matter with the European principle of equal treatment between part-time and full-time workers. This is justified by the fact that often differences in treatment of part-time workers result in discrimination between men and women.

For example, in Espadas Recio (C-98/15) the Court, while recognising that statutory social security pension is a field not regulated by the European Framework Agreement on part-time work, held that a Spanish provision concerning unemployment benefits was illegitimate. This provision excluded days not worked from the calculation of days in respect of which contributions have been paid, and therefore reduced the unemployment benefit payment period for vertical part-time workers. In this case, Spanish law was not considered in breach of clause 4(1) of the Framework Agreement (which does not apply to contributory unemployment benefit $)^{4}$ but in breach of Article 4(1) of Council Directive $79 / 7 / \mathrm{EEC}$ on the progressive implementation of the principle of equal treatment for men and women, because the majority of vertical part-time workers are women. According to the Court, women were adversely affected by such legislation and this is a kind of discrimination not allowed under European law. Article 3 of Council Directive 79/7/EEC says that statutory schemes providing protection against unemployment fall within the scope of the Directive and Article 4(1) forbids both direct and indirect discrimination on the ground of sex, in particular as regards the scope of schemes and conditions of access, the obligation to contribute and the calculation of benefits.

In closing this brief report, it is symbolic to make reference to another recent ECJ ruling in which the ECJ, with reference to a case involving Council Directive 97/81/EC concerning the Framework Agreement on part-time work, affirmed the central and essential role of European law. Indeed in O'Brien (C-432/17), the Court decided that the mechanism (for calculating the retirement pension entitlement) introduced by this Directive apply also to periods of service prior to the deadline for transposing the Directive (if the accrual of pension takes place both before and after the transposition deadline).

Concluding remarks

The rulings mentioned above show that, in recent years, the ECJ has always had a crucial role in identifying the

4. Clause 4 (1) and (2) of Directive 97/81/EC containing the Framework Agreement on part-time work says that, in respect of employment conditions, part-time workers shall not be treated less favourably than comparable full-time workers solely because they work part-time unless different treatment is justified on objective grounds and that, where appropriate, the principle of pro rata temporis shall apply. 
employment conditions that should be equally recognised and applied to every kind of worker (even parttime or fixed-term workers) and in strengthening the remedies against discrimination (in the technical sense). But it also seems that, if this difference in treatment doesn't result in discrimination, the Court often argues for the existence of sufficient objective grounds to allow differences in treatment between permanent workers and flexible ones.

\section{Transfer of undertaking}

\section{Prof. Niklas Bruun 5}

The Transfer of Undertakings Directive 2001/23/EC continues to raise complicated issues for national courts as well as for the ECJ. During 2018, however, the ECJ issued only two judgments regarding this Directive. Both of them were preliminary rulings requested from Spain. Whether this indicates that most issues regarding interpretation of the Directive have been clarified by the ECJ remains to be seen, but the existing extensive bulk of jurisprudence might in many cases offer arguments for national courts to claim that there exist earlier ECJ jurisprudence for most types of upcoming situations. In the following I discuss the two judgments given in 2018 .

\section{Case C-60/17: Angel Somoza Hermo}

In case C-60/17, Angel Somoza Hermo, the ECJ once again had to discuss the basic problem of the criteria that constitute an economic entity. The background is that the Directive is only applicable where there is a transfer of an economic entity retaining its identity and the national court wanted clarification on whether a transfer under the Directive took place in this case. Furthermore the ECJ was asked about the joint and several liability for obligations which arose before the transfer and had not been fulfilled.

The facts in the case were very much about the relationship between the Directive, Spanish law and a collective agreement in force regulating the employment relationships of security guards. Article 14 of the Spanish Collective State Agreement for Security Firms provides that a new acquirer of a contract for security services must take over the contracts of the employees assigned to that contract and workplace, if they have been assigned to it for at least seven months.

First the Collective Agreement defined the situation as a transfer within the meaning of the word under the Directive and Spanish law. The first question asked by the Spanish Court was whether Article 1(1) of the Directive must also be interpreted so that the Directive is applicable.

Second under the Directive there is an option to introduce joint and several liability. Under Article 3 of the Directive "Member States may provide that after the

5. Niklas Bruun is currently professor in Hanken School of Economics (Helsinki) and guest professor at Stockholm University. date of the transfer, the transferor and the transferee shall be jointly and severally liable in respect of obligations which arose before the date of transfer from a contract of employment or an employment relationship existing on the date of the transfer". It is also clear from Article 8 of the Directive that collective agreements more favourable to the employees are permitted on national level.

In this case, however, the Spanish legislation (the Spanish Workers' Statute Article 44(3)) stipulates that a transferor and transferee are in principle jointly and severally liable for pre-transfer obligations of the transferor for a period of three years. Contrary to this Article 14 of the Spanish Collective State Agreement for Security Firms stipulates that the new acquirer is not liable for payments and fees payable for work prior to the date on which the contract was taken over.

The ECJ had no problem in answering the first question in this case. One reason was that both the Directive and the Collective Agreement pointed in the same direction and indicated that the transaction was a transfer. The Court underlined that under the Directive the type of business at stake must be taken into account when assessing whether a transfer has taken place. In labourintense sectors, such as in the case at hand, a group of workers engaged in a joint activity on a permanent basis may constitute an economic activity especially if the new employer takes over a major part of employees specially assigned by the transferor to that task, in terms of number and skills. According to the Court the objective pursued by the Collective Agreement was the same as that pursued by the Directive and the Directive was applicable.

The second question was more complicated from the point of view of EU law. Here the Directive gives the option to the Member States to introduce joint liability for the transferor and the transferee. This option had been used by Spain, but in this case the Collective Agreement had derogated from the Spanish legislation. The ECJ quite correctly observed that the Directive as such tolerates different solutions regarding joint and several liability and that in this case the question at stake concerned the relationship between Spanish law and Spanish collective agreements which fell outside of the ECJ's competence.

\section{Case C-472/16: Jorge Luís Colino Sigüenza}

\section{- Facts}

The facts of the case related to Mr Colino Sigüenza who had been employed as a music teacher at the Municipal Music School of Valladolid (Spain) from 1996. Originally, that music school was directly managed by the municipal administration of Valladolid and Mr Colino Sigüenza was initially employed by the administration. From 1997, the municipal administration of Valladolid stopped managing the school directly and put out a series of calls for tenders for its management. The contractor designated after those successive procedures was, without interruption from that time until 31 August 
2013, the private company Músicos y Escuela, which carried on the business of the music school, managing the premises, facilities and instruments necessary for the provision of that service. Músicos y Escuela also took over some of the workers who had been employed by the municipal administration, including $\mathrm{Mr}$ Colino Sigüenza. That activity continued to be regarded as a service offered to citizens by the municipal administration of Valladolid as the Municipal School of Music.

Due to a reduction in the number of students of the Valladolid Municipal Academy of Music in the 2012-2013 school year, the sums paid by students for that service were no longer commensurate with the amounts to be paid by the municipal administration of Valladolid under the contract concluded with Músicos y Escuela, which led the latter to claim from the administration the sum of EUR 58403.73 in respect of the first term of that school year and EUR 48592.74 in respect of the second term .

Since the municipal administration of Valladolid refused to pay those sums in 2013 Músicos y Escuela requested the termination of the service contract on the ground of the administration's non-performance and claimed corresponding damages. In response, in August 2013, the municipal administration terminated the contract, alleging wrongful conduct by Músicos y Escuela as it had ceased its activities before the contractual enddate. The case was brought before a local court in Spain which by a number of final judgments delivered during 2014 and 2015 decided, firstly, that the municipal administration of Valladolid had breached the contract concluded with Músicos y Escuela, in so far as it provided for a guaranteed income irrespective of the number of students enrolled and that, by failing to comply therewith, the municipal administration had itself prevented Músicos y Escuela from continuing its activities, thus justifying the termination of that contract on the grounds of the wrongful conduct of the municipal administration. Secondly, since Músicos y Escuela had not fulfilled its obligations by having decided unilaterally to cease its activities on 31 March 2013, the damages which it sought were refused.

In the meantime, in August 2013, the municipal administration of Valladolid assigned the management of the Municipal Music School to another company In-pulso Musical and gave it, as it had done with Músicos y Escuela, the use of the premises, instruments and equipment necessary to that end. In-pulso Musical started its activities in September 2013 for the 2013-2014 school year. Following a new tendering procedure, the contract to In-pulso Musical was also awarded for the 2014-2015 and 2015-2016 academic years. That company did not hire any of the employees who previously worked in the Municipal School of Music and who were collectively dismissed by Músicos y Escuela.

\section{- Questions referred to the ECF}

Mr Colino Sigüenza raised a case against Músicos y Escuela, the municipal administration of Valladolid and In-pulso Musical to challenge his dismissal. In that case it was argued that In-pulso Musical had succeeded Músicos y Escuela as Mr Colino Sigüenza's employer. The court did not accept this, since nearly five months had elapsed between the dismissal and In-pulso Musical's taking over the management of the Municipal School of Music.

Mr Colino Sigüenza appealed against that decision before the referring court, the Tribunal Superior de Justicia de Castilla y León (High Court of Justice of Castile-Leon). He claimed among other things that there had been, in the present case, a transfer of undertaking to In-pulso Musical, so that operation cannot justify the termination of his employment contract since there was no valid reason for the termination.

In those circumstances, the Tribunal Superior decided to stay the proceedings and refer three questions to the ECJ for a preliminary ruling:

1. Should it be considered that there is a transfer for the purposes of Directive 2001/23/EC where the holder of a concession of a Municipal Music School, which receives all the material resources from that Municipality (premises, instruments, classrooms, furniture), has engaged its own staff and provides its services during the academic year, ceases that activity on 1 April 2013, two months before the end of the academic year, returning all the material resources to the Council, which does not resume the activity for the remainder of the academic year 2012/13, but awards a new concession to a new contractor, which resumes the activity in September 2013?

2. If the answer to the first question is in the affirmative, is it to be understood for the purposes of Article 4(1) of the Directive that, in the circumstances described - in which the failure of the main undertaking (the Municipality) to fulfil its obligations obliges the first contractor to cease its activity and to dismiss all its staff and immediately afterwards that main undertaking transfers the material resources to a second contractor, which continues with the same activity - the dismissal of the first contractor's employees has occurred for 'economic, technical or organisational reasons entailing changes in the workforce' or has it been caused by 'the transfer of the undertaking, business or part of the undertaking or business', a cause prohibited by that Article?

The third question was related to processual issues relating to the res judicata principle and Article 47 of the EU Charter. The ECJ declared the third question inadmissible due to lack of information and I will not discuss it further.

\section{- $\quad$ Argumentation by the ECF}

The ECJ started its answer to the first question by recalling that the aim of Directive 2001/23 is to ensure continuity of employment relationships within an economic entity, irrespective of any change of ownership. The decisive criterion for establishing the existence of a transfer within the meaning of that Directive is, therefore, the fact that the entity in question retains its iden- 
tity, as indicated by the fact, inter alia, that its operation is actually continued or resumed (Ferreira da Silva $e$ Brito and Others, $C-160 / 14$, paragraph 25 and the caselaw cited).

Furthermore, it is clear from the case-law of the Court that a temporary suspension, of only a few months, of the undertaking's activities cannot preclude the possibility that the economic entity at issue in the main proceedings retained its identity and that there was therefore a transfer of undertaking within the meaning of that Directive (see, to that effect, Ferreira da Silva e Brito and Others, C-160/14, paragraph 31).

In that regard, the Court has held, in particular, that the fact that the undertaking was, at the time of the transfer, temporarily closed and had no employees in its service is admittedly one factor to be taken into account when assessing whether an existing economic entity was transferred. However, the temporary closure of an undertaking and the resulting absence of staff at the time of the transfer do not of themselves preclude the possibility that there has been a transfer of an undertaking within the meaning of Article 1(1) of Directive 2001/23 (Bork International and Others, C-101/87, paragraph 16 and the case-law cited).

That conclusion applies in particular in a situation such as that at issue in the main proceedings, where, although the undertaking's activities ceased for five months, that period included three months of school holidays.

Consequently, the temporary suspension of the undertaking's activities and In-pulso Musical's failure to take over Músicos y Escuela's employees cannot preclude the possibility that the economic entity at issue in the main proceedings retained its identity and that there was therefore a transfer of undertaking within the meaning of that Directive.

The second question was whether the dismissal of the employees must be regarded as having been made for 'economic, technical or organisational reasons entailing changes in the workforce' or that the reason for that dismissal was 'the transfer of an undertaking, business, or part of an undertaking or business'.

Here the ECJ recalled that Directive 2001/23 is intended to safeguard the rights of employees in the event of a change of employer by allowing them to continue to work for the new employer on the same conditions as those agreed with the transferor (Fuuri, C-396.07, paragraph 28 and the case-law cited). The purpose of the Directive is to ensure, as far as possible, that the contract of employment or employment relationship continues unchanged with the transferee, in order to prevent the workers concerned from being placed in a less favourable position solely as a result of the transfer.

That being so, as is clear from the very wording of the first subparagraph of Article 3(1) of Directive 2001/23, the protection that the Directive is intended to provide only concerns workers who have an employment contract or employment relationship existing at the date of the transfer. Furthermore it must be observed that, under Article 4(1) of Directive 2001/23, the transfer of an undertaking, business or part of an undertaking or business must not in itself constitute grounds for dismissal by the transferor or the transferee.

The ECJ noted that Mr Colino Sigüenza's dismissal took place well before the date of the transfer of the activity to In-pulso Musical and that the reason for that termination of the employment relationship was the fact that it was impossible for Músicos y Escuela to pay its staff, a situation resulting from a breach by the municipal administration of Valladolid of the provisions of its contract with Músicos y Escuela. Thus, those circumstances would appear to militate in favour of a classification of the dismissal of the staff of Músicos y Escuela for 'economic, technical or organisational reasons', within the meaning of Article 4(1) of Directive 2001/23, provided, however, that the circumstances which gave rise to the dismissal of all the staff and the delayed appointment of a new service provider are not a deliberate measure intended to deprive the employees concerned of the rights conferred on them by Directive 2001/23, which it will be for the referring court to ascertain.

In the light of these considerations, the answer to the second question is that in circumstances such as those at issue in the main proceedings, where the successful tenderer for a service contract for the management of a municipal school of music ceases that activity two months before the end of the current academic year, proceeding to dismiss the staff, and the new contractor takes over the activity at the beginning of the next academic year, it appears that the dismissal of the employees was made for 'economic, technical or organisational reasons entailing changes in the workforce', within the meaning of that provision.

\section{- Concluding remarks}

In light of the previous case law of the ECJ, to which it largely referred in its judgment, it was in no way any surprise that the ECJ found that a transfer of undertaking had taken place in this particular case, although it can be noted that AG Tanchev came to the opposite conclusion by underlining that only the material assets had been taken over, a fact which he regarded as an indication that the identity had not been retained.

The more interesting part of the judgment relates to the question whether the reason for the dismissal of $\mathrm{Mr}$ Sigüenza was the transfer or whether it was economic, technical or organisational reasons which were not related to the transfer. From the facts of the case it can be observed that the transferor Músicos y Escuela's had issued a notice of dismissal to all its staff of 23 teachers and 3 administrative employees with effect from 8 April 2013. On 30 July 2013 Músicos y Escuela's was declared insolvent and was later dissolved by court order.

It seems clear that the employment relationships between Músicos y Escuela's and its employees had been terminated when the City Council in the Summer of 2013 put out a call for tenders for the provision of services for the management of a musical school. That again results in a situation where the answer by the ECJ to the first question of the Spanish court becomes more or less meaningless: it has no relevance for the previous 
employees of the transferor to know that a transfer between a company without any employees and the transferee took place in August/September 2013. In fact in this case the ECJ could have started by answering the second question, which would have given sufficient guidance for the referring court to decide the case.

For future practice the case contains an important message. For employees it can be valuable (the opposite might apply to employers) to try to prolong the period of continued employment (to take out holidays, or continue information and consultation procedures) with the transferor in order to still have a contract of employment or employment relationship on the date of the transfer. In such a situation the transferee will have to transfer those employees to the transferee on the date of the transfer and the transferee has an obligation to take them on board.

\section{Working Time}

\section{Anthony Kerr ${ }^{6}$}

23 November 2018 marked the 25th anniversary of the adoption by the Council of Directive 93/104/EC concerning aspects of the organisation of working time. Central to the operation of the Directive (and the subsequent codified Directive 2003/88/EC) is the definition of "working time", namely "any period during which the worker is working, at the employer's disposal and carrying out his [or her] activities and duties, in accordance with national laws and/or practice". Any period which is not "working time" is classified as a "rest period": see Article 2(1) and (2) of both Directives.

This binary divide between "work" and "rest" continues to create problems for national courts resulting in important rulings over the course of 2018 of the Court of Justice and the EFTA Court concerning the classification of "on-call time" and "travelling time".

The issue of "on-call time" first came before the ECJ in a reference from the Tribunal Superior de Fusticia de la Comunidad Valenciana: case C-303/98, Sindicato de Médicos de Asistencia Pública-v-Conselleria de Sanidad y Consumo de la Generalidad Valenciana.

Here the ECJ drew a distinction between time spent oncall by doctors where their presence and availability at a health centre was required and on-call time where doctors were contactable without their having to be at the health centre. Even though the latter were at their employer's disposal, they could "manage their time with fewer constraints and pursue their own interests". Accordingly, such on-call time, unless it was linked to the actual provision of primary care services, could not be regarded as "working time". This distinction between on-call time spent at and outside the workplace was reinforced by the ECJ decisions in case C-151/02,

6. Anthony Kerr is a Senior Counsel at the Bar of Ireland and an Associate Professor at the Sutherland School of Law in University College Dublin.
Landeshauptstadt Kiel - v- Faeger and case C-14/04, Dellas - v-Premier Ministre.

The essence of these decisions is that the time during which a worker is required to be available for his or her employer is to be classified as "working time" where the location of the worker is restricted by the employer. In Germany, this is regarded as "standby duty" which is seen as qualitatively different to time where workers can be wherever they like but remain available to the employer.

The distinction between a duty to be on standby and a duty to be available was recognised by the CJEU in the case of Matzak (C-518/15), a reference from the Cour du Travail de Bruxelles. Here, the claimant was a member of the fire service who was required to be available on call for work, for one week out of every four, during the evenings and at the weekend. This obliged him to remain contactable and, if necessary, report to the fire station as soon as possible and in any event within no more than eight minutes under normal conditions. Failure to comply with these requirements could lead to disciplinary, and possibly penal, sanctions.

The CJEU ruled that the obligation to remain physically at a place determined by the employer coupled with the "geographical and temporal constraints" resulting from the requirement to reach his place of work within eight minutes were such as to "objectively limit the opportunities which a worker ... has to devote himself to his personal and social interests". Accordingly, such on-call standby time was to be regarded as "working time".

At what point does stand-by time become availability time? According to EELC's German correspondent, when commenting on the decision of the Tribunal da Relação do Porto that availability time was "working time" (EELC 2018/33), the Bundesarbeitsgericht ruled, in January 2002, that a requirement to reach one's place of employment within 20 minutes rendered such standby time to be working time (6 AZR 214/00).

Ordinarily, the time spent travelling by a worker from home to his or her place of employment, and back to home, is not regarded as "working time". What if the worker does not have a fixed or habitual place of work? This issue arose in case C-266/14, Federación de Servicios Privados del sindicato Comisiones obreras $-v-T y c o$ Integrated Security SL. Here the company employed security technicians who had the use of a company vehicle in which they travelled from their homes to the places where they were to install or maintain security systems. The company counted the time spent traveling between customers as "working time" but not the time spent travelling between home and the first and last customer. The Court ruled that that time was "working time". A similar decision was reached by the Arbeidshof Antwerpen in the case of workers who were part of a vlinderploeg (butterfly team) for a cleaning company (EELC 2018/44).

The ambit of the ruling in Tyco,and in particular whether it only applied to peripatetic workers, was considered by the EFTA Court in case E-19/16, Thue - v- 
Government of Norway (http://www.eftacourt.int/ uploads/tx_nvcases/19_16_Judgment_EN.pdf). Here, the claimant was a member of a Special Response Unit based at a rural police station. His claim concerned assignments for the unit which involved driving between his home and the location where he was instructed to attend. The EFTA Court held that Tyco was not limited to cases where the worker did not have a fixed or habitual place of work and stated:

"Any journey to and/or from a location other than the worker's fixed or habitual place of attendance shall be deemed to have begun, and its return to have ended, either at the morker's home, or his fixed or habitual place of work, whichever is the more reasonable in the circumstances".

In considering this, account was to be taken of whether the journey to and/or from the location of the worker's assignment is shorter if travelling from the worker's home as opposed to his, or her, fixed or habitual place of attendance.

When the case returned to the Norges Hoyesterett, the Norwegian Government accepted that the time in question was "working time" within the meaning of the Directive and the Working Environment Act of 2005 (EELC 2018/32).

As Advocate General Sharpston noted in her opinion in Matzak, the claim was essentially concerned with the question of pay. Similarly, the EFTA Surveillance

Authority, in its submission in Theu, noted that the underlying dispute concerned the level of remuneration to which the claimant was entitled for the disputed journeys. Similar submissions were made by the European Commission.

In Matzak, the CJEU confirmed that Article 2 of the Directive does not require the Member States to determine the remuneration of periods of standby time. The Member States, however, are free to provide that such time should be paid for: see the Constantin case from Romania (EELC 2018/34).

The CJEU was also called upon to clarify the meaning of Article 5 of the Directive concerning weekly rest periods: Case C-306/16, Maio Marques Da Rosa. That Article provides that the Member States shall take the measures necessary to ensure that, "per each seven-day period", every worker is entitled to a minimum uninterrupted rest period of 24 hours plus the 11 hours' daily rest referred to in Article 3. Did this require the employer to provide the 24 hour rest period no later than the day following a period of six consecutive working days? The Court held that Article 5 required the Member States to ensure that every worker enjoyed a minimum uninterrupted rest period of 24 hours but it did not prescribe when that rest period must be granted. It followed that the 24-hour period could be provided at any time within each seven-day period.

\section{Annual leave}

\section{Fan-Pieter Vos, Luca Ratti}

\section{Introduction}

2018 was a very important year for the right to annual leave. We saw some very principled ECJ judgments which are likely to have a long lasting impact. In particular, the ECJ's interpretation of the Charter of Fundamental Rights of the EU (CFREU) has broadened the scope of the right to annual leave enormously. Aside from these judgments, we will discuss a few other cases.

\section{Independent contractors}

We start our review with an important case which actually was delivered in December 2017, Conley King (C-214/16). Mr King worked on a 'self-employed commission only' contract. It appears from the facts that both Mr King and his employer/principal, The Sash Window Workshop, assumed that the former had no right to paid annual leave. However, after their longlasting contract ended, he did claim payment of untaken leave. Already iIn the proceedings before the case got to the ECJ, it was already found that Mr King was a worker within the meaning of Directive 2003/88 and thus was entitled to annual leave (Article 7). As much of the leave had lapsed - UK law in principle requires leave to be taken in the same year as it was acquired - the referring court asked the ECJ how to deal with this. The ECJ held that Directive 2003/88 precludes national provisions or practices that prevent a worker from carrying over and, where appropriate, accumulating, until termination of his employment relationship, paid annual leave rights not exercised in respect of several consecutive reference periods because his employer refused to remunerate that leave.

Although the outcome of the case does not seem surprising, it demonstrated that the ECJ monitors any provisions on expiry or lapse of rights to annual leave very closely. A more practical consequence of the Conley King judgment is that it may have demonstrated to a greater audience that independent contractors also may also be entitled to annual leave. This is no surprise from a legal perspective - independent contractors can be workers within the meaning of Directive 2003/88 - but the message that independent contractors may be entitled to annual leave could be relevant in the debate on the gig economy and platform work.

Accrual of rights during parental leave In the Dicu case (C-12/17), the ECJ allowed a Romanian provision which excluded parental leave from being treated as a period of actual work during the reference period in which a worker accrues his/her annual leave. This had led a worker taking parental leave to accruing fewer rights to annual leave. Compared to sick leave and

7. Jan-Pieter Vos is a labour law teacher at Erasmus University in Rotterdam, The Netherlands. Luca Ratti is Associate Professor of European and Comparative Labour Law at Université du Luxembourg. 
maternity leave, parental leave appears to have been considered a more voluntary form of leave and therefore does not get the same protection.

6 November judgments

On 6 November 2018, the ECJ delivered what arguably are the judgments of the year in the Kreuziger case (C-619/16), joined cases Bauer and Willmeroth (C-569/16 and C-570/16) and the Max Planck case (C-684/16). These cases appear to have become landmark cases, as the ECJ both introduced a duty for the employer to enable employees to take their leave (Kreuziger, Max Planck) and enabled a direct appeal to Article 31(2) (right to annual leave) CFREU (Bauer et al. and Max Planck).

Regarding the first issue, both Kreuziger and Max Planck concerned workers who had outstanding, untaken leave at the moment that their employment contract had ended. While Article 7(2) of Directive 2003/88 enables the possibility to pay an allowance in lieu in this situation, it appears that the German (case) law at issue required that employees had actually requested to take the leave during their employment, before they would be entitled to this compensation. As they had not done requested (enough) leave, their employers refused to pay such an allowance.

The ECJ held that such an automatic loss of rights is not allowed under the terms of the Directive. As a weaker party in the employment relationship, the employee must not be dissuaded to from exercising the right to annual leave, especially when claiming that this right may have detrimental effects for the employment relationship. Any practice or omission by an employer that may potentially deter the worker from taking his or her right to annual leave is forbidden. In fact, the employer must ensure that the worker is given the opportunity to take the paid annual leave, by encouraging him or her, formally if need be, to do so, while informing him or her, accurately and in good time so as to ensure that the leave is still capable of procuring the rest and relaxation to which it is supposed to contribute. Further, if the worker does not take the leave, it will be lost at the end of the reference period or authorised carry-over period, or upon termination of the employment relationship where the termination occurs during such a period. Moreover, the employer must be able to prove that he it has done so.

These cases take employer obligations a whole lot further. Whereas an employer's primary task was to accommodate the employee wanting to take annual leave, the employer now has an active role and must ensure that the worker takes the leave. If he the employer does not, the employee will remain entitled to his outstanding leave or a corresponding payment at the end of the employment.

The second and most important aspect of the judgments was at issue in the cases Bauer et al. and Max Planck. The problem for private parties is that, in many EU Member States, it is difficult to enforce their rights if the national legislation is not compliant with EU legisla- tion. Private parties cannot directly invoke directives against each other and have to rely on state liability, which often is difficult. However, with Bauer et al. and Max Planck the ECJ circumvented this problem, by allowing private parties a direct appeal to Article 31(2) CFREU, forcing national judges to disregard provisions that are contrary to this Article.

Article 31(2) CFREU reads: "Every worker has the right to limitation of maximum working hours, to daily and weekly rest periods and to an annual period of paid leave." This Article is even more succinct and less concrete than Article 7 of Directive 2003/88, but it seems that the ECJ applies its case law on Article 7 of Directive 2003/88 equally to Article 31(2). Moreover, within the context of the CFREU, the right to annual leave is even dubbed an essential right of EU law.

A lot can be said about the ECJ's considerations, but from a practical point of view it is important to note that the ECJ acknowledges the direct horizontal effect of the right to annual leave of Article 31(2). The arguments by the ECJ recalled supranational sources (namely the Community Charter of the Fundamental Social Rights of Workers, the European Social Charter Revisited (revised) of 1996, and the ILO Convention No 132), to hold that the right to annual leave is not just an essential principle of EU social law (Bauer et al., para. 79), but "mandatory and unconditional in nature" so that Article 31(2) "is sufficient in itself to confer on workers a right that they may actually rely on in disputes between them and their employer in a field covered by EU law and therefore falling within the scope of the Charter" (Bauer et al., para 85).

Within an employment law context, we already were already aware of such direct effect in discrimination cases (e.g., Mangold, C-144/04 and Kücükdeveci, C-155/07), but this direct effect appeared to stem from the fact that the principle of non-discrimination on grounds of age was a general principle of EU law. A few years ago, a direct effect of Article 27 CFREU was denied in the case Association de Médiation Sociale $(\mathrm{C}-176 / 12)$ because that norm is not in itself sufficient to confer on individuals an individual right which they may invoke as such. Therefore, Bauer et al. appears to be the first employment law case, which acknowledges with such emphasis the direct effect of the CFREU.

As the right to annual leave now has direct effect, we probably will not be seeing state liability cases on this field anymore. This has always been a problematic way for employees who have fallen victim to wrong implementation of EU legislation, as the Francovich doctrine offered several ways out for EU Member States. For example, in 2018 the Danish case which featured in EELC 2018/10 saw the Government defending successfully in a case which concerned the wrong implementation of the right to annual leave. In 2009, the Pereda judgment (C-277/08) had rendered Danish provisions on annual leave and sick leave invalid, and the employee got sick (and therefore disadvantaged by national legislation) in 2010. The Supreme Court agreed with the employee that the Danish Government should have 
enacted an amended Holiday Act earlier than in January 2012. However, it considered that 1 January 2011 would have been a realistic deadline, as a result of which the employee remained empty-handed.

\section{Holiday pay}

In December 2018, the ECJ delivered another interesting judgment. In case C-385/17 (Hein), it had to rule on the definition of 'pay'. A collective agreement contained a definition of holiday pay which resulted in lower pay if in the reference period no/less work was performed due to short-time working. As the ECJ has held many times before, holiday pay must be comparable to regular pay, as otherwise this would be deemed to be deterring workers from taking their leave. This case turned out to be no different: this practice is not compatible with EU law. However, the ECJ made an interesting remark (paragraphs 46 and 47): incidental overtime, given its exceptional and unforeseeable nature does not, in principle, form part of holiday pay, but regular overtime does.

Interestingly, EELC 2018/43 featured a British case delivered prior to the Hein judgment - in which the Employment Appeal Tribunal held that both non-guaranteed and voluntary overtime should be taken into account when calculating holiday pay. To that end, it referred to EU case law to that date (Williams $-v-$ British Airmays, C-155/10). Had the Hein judgment been delivered earlier, the outcome would probably have been different.

\section{Concluding remarks}

As we said at the start of this review: 2018 has been a very important year for the right to annual leave. In particular the cases Conley King and the " 6 November judgments' have strengthened the right to annual leave. It now appears to have an even stronger position in EU law, firmly protected by Article 31(2) CFREU having a direct horizontal effect. The days that when the right to annual leave could still be regarded as some kind of luxury, are over.

\section{Collective Dismissals}

\section{Prof. Daiva Petrylaite $e^{8}$}

Four judgments about collective dismissals were reviewed during 2018 in EELC: two of them are judgments of the ECJ and two judgments of national Supreme Courts.

Collective redundancies and protection of female employees during pregnancy

The ECJ clarified the right to the protection from termination of employment of pregnant workers under Article 10 of Directive 92/85 (Pregnant Workers Directive) in the case of collective redundancies covered by
Directive 98/59 (Collective Redundancy Directive) in the Porras Guisado judgment (C-103/16).

Quoting the Advocate General (point 53 of the Opinion), the ECJ stated that, when a pregnant worker (or a worker who has recently given birth or is breastfeeding) is dismissed within the context of a collective redundancy procedure, she belongs both to the group of workers protected under Directive $92 / 85$ and to the group of workers protected under Directive 98/59; on that basis, she should benefit, at the same time, from the rights provided for by both of those Directives. With references to its previous judgments, the ECJ held that when the dismissal decision is taken for reasons essentially connected with the worker's pregnancy, it is incompatible with the prohibition on dismissal laid down in Article 10 of the Pregnant Workers Directive; by contrast, a dismissal decision taken during the period from the beginning of pregnancy to the end of the maternity leave for reasons unconnected with the worker's pregnancy would not be contrary to Article 10 of Directive 92/85 (Danosa, C-232/09). Meanwhile, according to the Court, Article 1(1)(a) of the Collective Redundancy Directive states that 'collective redundancies' refers to dismissals effected by an employer for one or more reasons not related to the individual workers concerned, provided that certain conditions concerning numbers and periods of time are satisfied (Rodríguez Mayor and Others, C-323/08). The Court found that a reason or reasons, not related to the individual workers concerned, for making the collective redundancies within the meaning of Article 1(1) of Directive 98/59 fall within the exceptional cases not related to the condition of pregnant workers within the meaning of Article 10(1) of Directive 92/85. On that basis, the Court concluded that Article 10(1) of Directive 92/85 must be interpreted as not precluding national legislation which permits the dismissal of a pregnant worker because of a collective redundancy within the meaning of Article 1(1)(a) of Directive 98/59.

This judgment of the Court is significant, first of all in its interpretation of the scope of the female workers' protection against termination from employment enshrined in the Pregnant Workers Directive. Secondly, the reasons that force the employer to carry out collective redundancies according to the Collective Redundancy Directive, at the same time, are recognised as legitimate and sufficient to apply such redundancy procedures, inter alia, to pregnant workers.

Definition of 'undertaking controlling the employer' in case of collective redundancies

The Court in the judgment Miriam Bichat and Others (joined cases C-61/17, C-62/17 and C-72/17) clarified Article 2(4) of Directive 98/59 (Collective Redundancy Directive) as far as it states that the decision regarding collective redundancies is being taken by an 'undertaking controlling the employer'. According to the Court, in interpreting the origins and the objective of the first subparagraph of Article 2(4) of Directive 98/59, the term 'undertaking controlling the employer' covers all 
undertakings which, by virtue of belonging to the same group or having a shareholding that gives it the majority of votes in the general meeting and/or the decisionmaking bodies within the employer, are able to require the latter to adopt a decision contemplating or planning for collective redundancies. In addition, the Court stated that a simple contractual relationship, in so far as such a relationship does not allow an undertaking to exercise a decisive influence on dismissal decisions taken by the employer, cannot be considered sufficient to establish a situation of control within the meaning of the first subparagraph of Article 2(4) of Directive 98/59. The resuming Court clarified that the first subparagraph of Article 2(4) of Directive 98/59 must be interpreted as meaning that the term 'undertaking controlling the employer' covers all undertakings linked to that employer by shareholdings in the latter or by other links in law which allow it to exercise decisive influence in the employer's decision-making bodies and compel it to contemplate or to plan for collective redundancies.

In this judgment, the Court gave a significant explanation concerning the term 'undertaking controlling the employer', first of all, taking into account that this term doesn't refer to the national law, it should be interpreted in the same way throughout the European Union; secondly, the Court referring to its previous judgments clarified that the term 'control' refers to a situation in which an undertaking may adopt a strategic or commercial decision compelling the employer to contemplate or to plan for collective redundancies. On this basis, the Court stated that the term 'undertaking controlling the employer' in the context of the Directive, should be applied in a narrower sense, i.e. as an undertaking whose influence is ensured through shareholdings and voting rights but not based on a contractual or de facto influence.

\section{The Austrian Supreme Court judgments in}

collective redundancy cases

Regarding national precedents, only two cases, both Austrian, were reviewed in 2018. In the first judgment of the Austrian Supreme Court (EELC 2018/15) the question of applicable law was raised (the dispute arose as to whether the law of Austria or Germany applied), however the Court did not interpret or define the issues related to collective redundancies.

In another judgment (EELC 2018/38) the Austrian Supreme Court held that the employer must notify the Employment Service when it is contemplating collective redundancies, even if they are carried out by mutual agreement. The duty of notification is triggered if the employer proposes a mutual termination agreement to a relevant number of employees, provided the offer is binding and can be accepted by the employees within 30 days. If the employer fails to notify the Employment Service, any subsequent redundancies (or mutual terminations of employment occurring on the employer's initiative) are void, even if effected after 30 days.

Thus, the Court noted that collective redundancies should not be limited to cases where employment con- tracts are terminated at the initiative of the employer (for economic and other reasons not related to the employee), but also the termination of the employment contract by mutual agreement if it is initiated by the employer and the circumstances indicate that the initiative was caused for the same reasons as other collective redundancies during the fixed period.

\section{Gig economy in 2018}

\section{Andrej Poruban ${ }^{9}$}

In recent years, digital technologies have quickly become a focal point for discussions about the future of the traditional world of work. One of the major transformations has been the emergence of the so-called 'gig economy' under which the demand and supply of working activities is matched via mobile applications. These online platforms have diverse origins and encompass multiple services such as the ride-hailing system, food delivery, cleaning, home repairs and other skilled or routine work. The growth of this new phenomena raises new questions concerning misclassification of employment relationships.

In 2018, litigation in cases of worker/employee or selfemployed contractors has flourished throughout Europe with different outcomes: e.g. in Spain - Juzgado de lo Social núm. 11 de Barcelona, 29 May 2018, Juzgado de lo Social núm. 6 de Valencia, 1 June 2018, Juzgado de lo Social núm. 39 de Madrid, 3 September 2018; Italy Tribunale Ordinario di Torino, 7 May 2018 (nevertheless, the Court of Appeal didn't uphold the decision, 11 January 2019), Tribunale di Milano, 10 September 2018; France - Cour de cassation, 28 November 2018.

One of the high profile cases was also featured in EELC 2018/9 and focused on the most visible example of the gig economy. In Uber B.V. E Others $-v-$ Aslam E Others the Employment Appeal Tribunal (EAT) dealt with the practical realities of the relationship between Uber and its associated companies and their drivers. The group of former London drivers brought claims for the national minimum wage and paid annual leave. These entitlements extend to every 'worker'. The 'worker' is an intermediate category in UK law in between an 'employee', who is obliged to work for an employer when required in accordance with her/his contract, and has the greatest level of employment protection and an 'independent contractor', who works autonomously. In the Employment Tribunal the judge found that they were 'workers', rather than selfemployed contractors, broadly as they were not in control of setting fares and were subject to various forms of control through the eponymous software app. That decision was upheld by the EAT. In the meantime, on

9. Andrej Poruban is an Assistant professor at the Faculty of Law of Comenius University in Bratislava, Slovakia. 
19 December 2018, the Court of Appeal rejected Uber's appeal (Uber B.V. E Ors - v-Aslam E Ors [2018] EWCA Civ 2748) and held that the original Employment Tribunal decision was correct - the claimants were entitled to the rights which come with worker status. The majority of the Court of Appeal clarified two pivotal issues. The drivers did not have a contract with their passengers and they could be considered to be working for Uber when they logged onto the app in their territory in order to be ready and willing to accept any trips offered. It is worth nothing that Uber gained some judicial support. One judge disagreed and raise some compelling points in favour of Uber's arguments. In a dissenting opinion, he found that the drivers were independent contractors and argued that the written terms in place are perfectly explicit and reflected that drivers provide their services to the passengers as principals, with Uber's role being that of intermediary. In this context, it's not surprising that the Court of Appeal has given Uber permission to appeal to the Supreme Court.

The gig economy was also questioned by the ECJ in a landmark judgment Asociación Profesional Elite Taxi-v - Uber Systems Spain SL (C-434/15). The Spanish commercial court referred questions for a preliminary ruling on whether services provided by Uber are regarded as transport services, information society services or a combination of both. The ECJ recognised that the activity of the platform is not limited to a mere electronic intermediation and qualified Uber as a service in the field of transport. The company has created a supply of urban transport services itself and has organised it by selecting the drivers, providing an application which is indispensable for both the drivers and people who wish to make a journey and regulating some key aspects of their offer. The ECJ also noted that Uber exercises a certain control over the quality of the vehicles, the drivers and their conduct which can, in some circumstances, result in them being excluded. Of course, this ruling remains silent about the characterisation of the relationship between platform/driver/passenger and leaves such effort to domestic legislation and case law. However, it may have a broader impact from a labour law perspective because the ECJ dealt with the same argumentation of Uber which claim to be solely an intermediary and de facto deny the role and responsibilities of an employer.

Despite developments in 2018 there is no clear-cut answer to the question of the employment qualification within the various platforms related to the gig economy and therefore case-by-case analysis is still required. In this context is therefore interesting to see the initial reactions of International Labour Organization. The report on the Future of Work published on January 2019 recommends to develop an international governance system for crowdworking websites and app-mediated work that sets and requires platforms to respect minimum rights and protections and looks to the ILO Maritime Labour Convention, 2006 as a model.

\section{Fundamental rights: privacy and freedom of expression}

\author{
Prof. Stein Evju ${ }^{10}$
}

Privacy and work intersect in many different ways. While private life and privacy, not necessarily one and the same, enjoy protection on the one hand they may, on the other hand, be impacted on by obligations vested in the employment relationship. The borderline between right and wrong is a multifarious challenge, illustrated in different ways by three cases reported in 2018, brought together here under the headline 'fundamental rights'.

Notwithstanding ECJ case law, most recently last year's judgment in Matzak (C-518/15), the distinction between standby duty and on-call availability is not clear cut in practice. The Portuguese Court of Appeal judgment (EELC 2018/33) and the comments triggered by it illustrate the point, at the same time highlighting a particular aspect of privacy rights. If a worker on standby or on call - terminology is not decisive - is free to move about and stay wherever s/he likes, the time thus spent as a rule is not deemed working time; it is only time actually spent working when called upon that is regarded as such. Restrictions on the worker's freedom in time or space may lead to a different conclusion. The intensity of measures involved in being available may do the same. Judging from comments made on the Portuguese decision the working time issue is at the outset considered differently in different jurisdictions. That may be the case also where a worker is required to carry an active GPS tracker outside of working hours for the purpose of availability. This may in itself or, depending on an individual balancing of interests, amount to a violation of GDPR-based privacy protection and, as the case may be, of the right to privacy under Article 8 ECHR.

So-called social media is fertile ground for conflictual issues in the interface between private life, privacy rights and work-related obligations. Posts or mere 'likes' on internet platforms may be seen as offensive, inconsistent with and thus harmful to the employer's values and reputation, as exemplified by the Belgian judgment EELC 2018/4 - upholding dismissal for serious misconduct on grounds of 'liking' a website associated with racist activity. Cases of this kind immediately engages freedom of expression, as guaranteed by Article 10 ECHR. Balancing this freedom with other freedom rights and conflicting interests is no mean task. The best to be said is that it requires comprehensive and careful consideration in the individual case, keeping in mind

10. Stein Eviu is a professor emeritus at the Department of Private law, University of Oslo. 
that dismissal - as the ECtHR has put it (e.g. in Ognevenko, 44873/09, paragraph 83) - is the most severe disciplinary sanction or penalty. Proportionality considerations beg to play an essential part.

Internet activities during working hours is another arena of potential conflict. An employer may legitimately restrict or prohibit employees' use of workplace IT resources during working hours. If detected, transgressions may lead to sanctions, similarly engaging a balancing of interests. The German Bundesarbeitsgericht (BAG) judgment (EELC 2018/5) is concerned with a prior stage, so to say, which likewise involves balancing of interests. Monitoring by the employer of employees' use of IT resources is permissible, but up to a point. Privacy rights under Article 8 ECHR and GDPR-related issues are involved. Whether information obtained through unlawful monitoring or surveillance may be used in evidence is in principle another matter. The BAG judgment and comments from other jurisdictions demonstrate that there is no unanimous or unambiguous answer to this. Some exclude unlawfully gathered evidence from use in court, whereas others do not. The landmark decision by the ECtHR (Grand Chamber) in Bărbulescu (no. 61496/08) elaborates on considerations relevant to assessments of conformity or violation of Article 8 ECHR. However, it does not provide a straightforward answer to whether unlawfully gathered evidence may be used in court. Arguably, an answer in the negative may be inferred by implication. It is a point of interest how this will play out with time in domestic case law.

\section{Collective Labour Law}

\section{Prof. Stein Evju $u^{11}$}

There were merely two judgments in the field of collective labour law that featured in EELC 2018, both from domestic courts. Collective agreements are recognised as an important means of regulation over a wide range of issues in EU law. Yet there is no definition or autonomous concept of 'collective agreement' in EU legislation or case law. This is deferred to national law, and the concept differs significantly across jurisdictions. The Danish Supreme Court decision (EELC 2018/22) is a case in point.

Formalities are few and far between when it comes to concluding a collective agreement between parties in Danish law, be that at national or at local level. The same is true for the other Scandinavian countries, Norway and Sweden. If collective bargaining and subsequent mediation fail to arrive at a settlement, as a rule recourse is taken to collective action. If the parties still do not reach a compromise on a renewed agreement, state intervention of some form is potentially a means to break the impasse. As opposed to Sweden, in Denmark

11. Stein Evju is a professor emeritus at the Department of Private law, University of Oslo. and Norway there is a certain practice in this regard, however in different forms.

In Denmark, the prevailing practice, if state intervention is deemed necessary, is to adopt an ad hoc act by the Folketinget (National Assembly) on renewal of the collective agreement at issue, possibly with amendments drawn from preceding mediation proposals. The 'intervention act' sets a period of validity corresponding to that which would apply had the parties themselves arrived at an agreement. The objective of an 'intervention act' is indeed to establish a mutually binding regulation for the parties in the form of a collective agreement with all legal effects otherwise attributed to voluntary agreements. Similarly, in Norway there is no permanent legislation empowering the Government or a Minister to intervene. If collective action is seen to persist with no prospect of reaching a settlement, the Stortinget (National Assembly) may adopt an ad hoc act, not itself imposing a collective agreement but referring the dispute for settlement by an independent arbitration body, the National Wages Board. Pursuant to standing legislation, the Board's decisions have the same legal effect as a collective agreement, that is, in law they are collective agreements in their own right.

State intervention of this kind may be subject to criticism by ILO supervisory bodies, under ILO Convention No. 87, or by the European Committee of Social Rights pursuant to Article 6(4) of the European Social Charter (revised), which has been the case for both countries a number of times. However, it is significant to note that intervention is not per se a violation. This depends on an assessment of the individual case of intervention in pursuance of the ILO bodies' doctrine on 'essential services' etc. or the European Social Charter Article G exception clause, as demonstrated in case law of the supervisory bodies.

It must be emphasised, also, that such forms of ad hoc intervention are fundamentally different from adopting new legislation or executive measures of a general kind. Collective agreements in the Scandinavian context are binding only on the parties to the agreement and their members concerned. They have no erga omnes effect, and no mechanisms of extension obtain.

Whether something is categorised in law as a collective agreement is self-evidently fundamentally important in many regards. In EU law this includes the possible implementation of, or derogation from, EU legislation. The latter is demonstrated by the Danish Supreme Court case, where the issue was whether the outcome of the intervention act could be deemed a 'collective agreement' within the meaning of Article 18 of the Working Time Directive (2003/88/EC). It is readily understandable that the Danish courts chose not to refer questions on this to the ECJ, which would run a risk of interference with embedded industrial relations. More generally, considering the widely differing concepts of collective bargaining and collective agreements across Member States it might open a Pandora's Box with incalculable consequences. 
What a collective agreement can lawfully stipulate, once it obtains, is a different matter. The freedom of collective agreement parties is constrained by domestic and EU law. This is trite. So is its being commonplace that collective agreements lend themselves to interpretation. Methods of interpretation may differ, but it is common ground that courts construing collective agreement provisions should take due account of relevant legislation, to avoid conflicting outcomes as far as possible. Both aspects are illustrated by the German case (EELC 2017/45), in which the Court, seemingly, considered ECJ case law and German legislation implementing the Part Time Workers Directive (97/81/EC) arriving at a conclusion on what at the outset was an interpretation issue. 